\title{
Variability Among Turnip Mosaic Potyvirus Isolates
}

\author{
Livia Stavolone, Daniela Alioto, Antonio Ragozzino, and Jean-François Laliberté
}

First, second, and third authors: Istituto di Patologia vegetale, Universita degli studi di Napoli Federico II, 80055 Portici (NA) Italia; and fourth author: Centre de recherche en virologie, Institut Armand-Frappier, 531 Boulevard des Prairies, Ville de Laval, Québec Canada H7N 4Z3. Accepted for publication 30 July 1998.

\begin{abstract}
Stavolone, L., Alioto, D., Ragozzino, A., and Laliberté, J.-F. 1998. Variability among turnip mosaic potyvirus isolates. Phytopathology 88:12001204.

Eight turnip mosaic potyvirus (TuMV) isolates from the Campania region of Italy were characterized. Experiments based on host range and symptomatology indicated that the isolates were biologically different. In addition, the isolates, with the exception of ITA1 and ITA3, were distinguished from each other by using a combination of monoclonal antibodies recognizing the coat protein. Single-strand conformation polymorphism

(SSCP) analysis of the coat protein gene revealed that each isolate produced a specific SSCP profile, except for isolates ITA1 and ITA3. This study indicates that (i) even in a small geographical region, there is a great deal of variation in TuMV isolates; (ii) the use of a set of four differential hosts does not always specify the same pathotype in different environments; (iii) the TuMV isolates with the same pathotype on Brassica napus test lines can still differ in host range, symptoms, serology, and SSCP; and (iv) there was perfect correlation between the panel of antibodies and SSCP in differentiating among the isolates; ITA1 and ITA3 were indistinguishable by either assay.
\end{abstract}

Turnip mosaic virus (TuMV) is a member of the potyvirus group. It occurs worldwide in a large number of economically important cultivated crops and in wild plants (16). In an extensive survey in many countries, TuMV was found to be second in importance for crop losses, behind cucumber mosaic virus (28). In Italy in particular, likely due to the mild weather all year round, TuMV is widely spread in garden and ornamental plants, as well as in several wild plant species that act as alternative hosts. TuMV has also been found in mixed infections with other viruses that produce a more severe disease than either virus alone $(1,3)$.

Sources of resistance genes to TuMV have been recorded (22). However, a knowledge of pathotypic variation and distribution of TuMV is necessary before resistance genes can be efficiently deployed as part of an integrated control strategy. The existence of several TuMV strains has been reported based on their host range and symptomatology $(6,8,14,20,21,27,29,32)$. They have also been identified on the basis of serological properties of the capsid protein $(\mathrm{CP})(8,10,13,33)$. Finally, TuMV isolates have been classified according to the sequence of the 3 '-untranslated region of the genomic RNA $(12,19)$. In the above studies, the geographic origin of the TuMV isolates was very diverse, with many from Europe and Asia and somewhat fewer from North America and Australia.

Because of this worldwide diversity, we investigated the variability of TuMV in a small area of the Campania region of Italy. We hypothesized the existence of a broad TuMV population based on diverse symptomatology on the same host species or on infection of plants phylogenetically distant. In this report, eight of those TuMV isolates were selected and characterized. Experiments based on host range and induced symptoms indicated that the isolates were biologically different. In addition, the isolates, with the exception of ITA1 and ITA3, were distinguished from each other by using a combination of monoclonal antibodies recognizing the $\mathrm{CP}$ and a single-strand conformation polymorphism

Corresponding author: J.-F. Laliberté

E-mail address: jean-francois_laliberte@iaf.uquebec.ca

Publication no. P-1998-0910-01R

(C) 1998 The American Phytopathological Society
(SSCP) analysis of the CP gene. This study then indicates that even in a very restricted geographic region several different isolates of TuMV can coexist.

\section{MATERIALS AND METHODS}

Virus isolates. The eight Italian TuMV isolates were collected in the Campania region of Italy. The Canadian strain was described by Nicolas and Laliberté $(17,18)$. Single-lesion isolates were produced on Chenopodium quinoa to ensure the separation of a single pathotype from a possible mixed population. Isolates were maintained in Brassica perviridis L.H. Bailey (L.H. Bailey) (tendergreen) and stored in $C$. quinoa freeze-dried leaves or in B. perviridis and $B$. rapa leaves at $-20^{\circ} \mathrm{C}$.

Biological characterization. All biological tests were carried out by mechanical inoculations of leaf tissue ground in potassium phosphate buffer $(10 \mathrm{mM}, \mathrm{pH} 7.5)$ in a 1:10 (wt/vol) ratio. Leaf extracts were gently rubbed on healthy test plant leaves after adding 800-grit Carborundum as an abrasive. The inoculated plants were maintained in an insect-proof glasshouse at 18 to $25^{\circ} \mathrm{C}$.

TuMV isolates were tested on four differential lines of B. napus subsp. oleifera (oilseed rape and swede) provided by J. A. Walsh (Horticulture Research International, Wellesbourne, United Kingdom) (9). Five plants per each line were inoculated at the four-trueleaf stage with single-lesion isolates. They were monitored for the production of local and systemic symptoms. Inoculated and uninoculated leaf samples were tested by double-antibody sandwich enzyme-linked immunosorbent assay (DAS-ELISA) (4) for the presence of TuMV by using the anti-TuMV ELISA kit (Bioreba AG, Basel, Switzerland) according to the manufacturer's instructions. The ELISA was carried out 2 and 4 weeks after inoculation to verify local and systemic infection of inoculated plants. The whole test was repeated at least twice for ITA8 and three times for the other isolates.

Serological characterization. TuMV isolates were tested for their serological relationships in an indirect plate-trapped antigen ELISA. Twenty monoclonal antibodies (MAb) provided by M. F. Clark (Horticulture Research International, East Malling, United Kingdom) were used for the test. The antibodies were produced against four different TuMV strains: MAb 51, 
67, and 68 against the CZE strain; MAb 58, 59, 60, 61, 70, and 71 against the UK1 strain; MAb 72, 73, 74, 75, 76, and 77 against the CDN strain; and MAb 78, 79, 80, 81, and 82 against the GK strain.

Leaf sap from infected $C$. quinoa was diluted 1:30 in $50 \mathrm{mM}$ carbonate buffer, $\mathrm{pH} 9.6$, pipetted into microtiter plates, and kept overnight at $4^{\circ} \mathrm{C}$. Plates were incubated for $2 \mathrm{~h}$ at $37^{\circ} \mathrm{C}$, first with $\mathrm{MAb}$ and then with peroxidase-conjugated anti-mouse immunoglobulin G (Sigma Immunochemicals, St. Louis), both diluted in phosphate-buffered saline, $\mathrm{pH} 7.5$, containing $0.5 \%$ Tween-20, $2 \%$ polyvinylpyrrolidone, and $0.2 \%$ bovine serum albumin. For the color reaction, plates were incubated for 5 min with $3,3^{\prime}, 5,5^{\prime}$ tetramethylbenzidine as a substrate. Readings were taken at $450 \mathrm{~nm}$ using a Titertek Multiskan Plus MK II ELISA reader (Titertek Instruments, Inc., Huntsville, AL). Colorimetric readings at least twice the value of the negative control (healthy $C$. quinoa) were considered as positives.

SSCP analysis. Total RNA was extracted from fresh, frozen, and freeze-dried $C$. quinoa- and B. perviridis-infected leaves. Frozen and fresh leaf tissue $(50 \mathrm{mg})$ were ground in $0.5 \mathrm{ml}$ of extraction buffer (1.0 M Tris-HCl, pH 9.0; 10 mM EDTA; $100 \mathrm{mM} \mathrm{LiCl}$; and $2 \%$ sodium dodecyl sulfate), added to an equal volume of phenol, and incubated at $70^{\circ} \mathrm{C}$ for $5 \mathrm{~min}$. The water phase was recovered after centrifugation and extracted with phenol, phenol/chloroform (1:1), and chloroform. RNA was precipitated with ethanol for $60 \mathrm{~min}$ at $-70^{\circ} \mathrm{C}$ and resuspended in $10 \mu \mathrm{l}$ of water. Freeze-dried samples were processed in the same way after rehydration in phosphate buffer, $\mathrm{pH} 7.5$ (1:10). One-tenth of the RNA extraction was used to synthesize oligo(dT)-primed cDNA with Superscript II reverse transcriptase (Gibco BRL, Burlington, Ontario, Canada). For amplification of the CP gene, a primer pair based on the nucleotide sequence of the Canadian strain was used (18): JF7a (5'-GGTGTTGAGGCTTGGATCCGAACCATGGCAGGTGAAAG-3') (nucleotides 8,737 to 8,774 of the RNA genome) and FT4a (5'-TATAGTCTACCAGGATCCACTTCATAACCCCTGAAGGCC-3') (complementary to nucleotides 9,605 to 9,643 of the RNA genome). Taq DNA polymerase (BIO/CAN Scientific, Mississauga, Ontario, Canada) was used with one-fifth of the reverse-transcriptase (RT) product for polymerase chain reaction (PCR) amplification. PCR conditions were 2 cycles of $1 \mathrm{~min}$ at $94^{\circ} \mathrm{C} ; 32$ cycles of $30 \mathrm{~s}$ at $94^{\circ} \mathrm{C}, 30 \mathrm{~s}$ at $50^{\circ} \mathrm{C}$, and $2 \mathrm{~min}$ at $72^{\circ} \mathrm{C}$; and 1 cycle of $5 \mathrm{~min}$ at $72^{\circ} \mathrm{C}$. For total RNA extracted from infected leaves, the annealing temperature was occasionally increased to $55^{\circ} \mathrm{C}$, and $0.1 \%$ skim milk powder was added to the PCR mix to obtain specific PCR products in a higher amount. Restriction endonucleases HinfI and EcoRI were incubated with RT-PCR products to obtain fragments of a maximum of $280 \mathrm{bp}$ in length. Cleaved DNA was denatured by heating $10 \mathrm{~min}$ at $95^{\circ} \mathrm{C}$ in 0.3 volume of formamide containing $20 \mathrm{mM}$ EDTA and $0.1 \%$ bromophenol blue and immediately cooled on ice. Electrophoresis was carried out in a Miniprotean II apparatus (Bio-Rad Laboratories, Mississauga, Ontario, Canada) in a $10 \%$ polyacrylamide bisacrylamide $(29: 1)$ 1-mm-thick gel with $1 \times \mathrm{TBE}$ buffer $(90 \mathrm{mM}$ Tris, $90 \mathrm{mM}$ borate, and $2 \mathrm{mM}$ EDTA), $\mathrm{pH} 8.0$. The running conditions were 200 $\mathrm{V}$ (constant) and $20 \mathrm{~mA}$ for 1 to $2 \mathrm{~h}$ at room temperature (18 to $25^{\circ} \mathrm{C}$ ). The gel was silver-stained (2).

TABLE 1. Origin of the Italian isolates

\begin{tabular}{lll}
\hline Isolate & \multicolumn{1}{c}{ Plant } & \multicolumn{1}{c}{ Symptoms } \\
\hline ITA1 & Brassica ruvo & Severe leaf crinkling \\
ITA2 & Cheirantus cheiri & Rugose mosaic \\
ITA3 & Brassica ruvo & Severe vein clearing \\
ITA4 & Brassica rapa var. rapa & Chlorosis and ring spotting \\
ITA5 & Brassica rapa var. septices & Diffuse yellowing and browning \\
ITA6 & Matthiola incana & Flower color breaking \\
ITA7 & Raphanus sativus & Veinal and interveinal clearings \\
ITA8 & Papaver rhoeas & Leaf crinkling \\
\hline
\end{tabular}

\section{RESULTS AND DISCUSSION}

For 3 years, starting in the fall of 1993, a large screening of TuMV-infected plants was carried out in the Campania region of Italy. Many isolates were collected from several fields randomly chosen in two highly cultivated areas of approximately $1,500 \mathrm{~km}^{2}$ each. Plants showed a broad variability of reaction to TuMV: the same host could be immune, resistant, or show a different symptomatology in different cultivated areas and even in different infected plants in the same field. DAS-ELISA and immunosorbent electron microscopy (15) confirmed all the isolates as TuMV. Eight isolates were selected based on the natural host infected and on the distinctive symptom reactions (Table 1).

TuMV isolates have previously been characterized by inoculation on four differential lines of B. napus (9). Pathotypes were discriminated by three different symptom phenotypes: local infection only (resistance), systemic infection (susceptibility), and no infection (apparent immunity). Pathotypes were further differentiated on the basis of the initial local symptoms they induced in susceptible plants, which could be either chlorotic or necrotic. With this approach, 12 pathotypes were reported. These same lines were used to investigate whether the eight TuMV isolates studied here could be ascribed to specific pathotype groups. Patterns of reactions induced in differential B. napus lines by the isolates are shown in Table 2. The inoculations were repeated several times, and ELISA on inoculated and uninoculated leaves confirmed the presence or absence of viral particles. With this test, we were able to assign the isolates to five or six pathotype groups. However, classification by using these $B$. napus differential lines showed some limitations. Although the eight Italian isolates could be ascribed to pathotype groups, in some cases, assignation to a particular group proved to be difficult. It was not possible to definitely ascribe isolates ITA4, ITA5, and ITA6 to pathotype group 3 or 5, since the local lesions induced in 'Rape R4', which always started as chlorotic, could either stay chlorotic or turn necrotic in different plants that had been simultaneously inoculated under the same conditions. Furthermore, isolates ITA1 to ITA7 were previously tested by Jenner and Walsh (9). Only ITA1 and ITA2 were assigned to the same groups as in this study. This discrepancy may result from different environmental growth conditions affecting the plant response to infection.

The TuMV isolates were also compared on 27 plant species (Table 3). Plants of the same age were inoculated at the same time and observed over 7 weeks for production of local and systemic symptoms and for symptomatological variability within and among isolates. Several species reacted similarly to all isolates. For example, Cucumis sativus, Datura stramonium, Lactuca sativa, and Ocimum basilicum did not show any symptoms and were not infected when tested by ELISA. Equally, systemic mosaic symptoms, and in some cases, leaf distortion were observed for all isolates on B. pekinensis, B. rapa var. rapa, C. quinoa, Matthiola incana, Nicotiana benthamiana, Petunia hybrida, and Zinnia elegans. Nevertheless, systematic analysis of the symptoms suggested that the isolates were all biologically distinct.

TABLE 2. Reactions of turnip mosaic virus isolates on differential Brassica napus lines

\begin{tabular}{lccccc}
\hline & \multicolumn{5}{c}{ Plant line } \\
\cline { 2 - 5 } Isolate & Rape S6 & Rape R4 & Swede 165 & Swede S1 & Pathotype \\
\hline ITA1 & $+^{\mathrm{a}}$ & + & 0 & $\mathrm{R}$ & 6 \\
ITA2 & + & $\mathrm{R}$ & 0 & $\mathrm{R}$ & 9 \\
ITA3 & + & + & 0 & $\mathrm{R}$ & 6 \\
ITA4 & + & $+\mathrm{N}$ & 0 & + & 3 or 5 \\
ITA5 & + & $+\mathrm{N}$ & 0 & + & 3 or 5 \\
ITA6 & + & $+\mathrm{N}$ & 0 & + & 3 or 5 \\
ITA7 & $\mathrm{R}$ & $\mathrm{R}$ & 0 & $\mathrm{R}$ & 2 \\
ITA8 & + & + & 0 & 0 & 10 \\
\hline
\end{tabular}

a $0=$ No infection, immune; $\mathrm{R}=$ local infection only, resistant $;+=$ systemic infection, susceptible; and $\mathrm{N}=$ local necrotic symptoms. 


\begin{tabular}{|c|c|c|c|c|c|c|c|c|}
\hline \multirow[b]{2}{*}{ Species } & \multicolumn{8}{|c|}{ Isolate } \\
\hline & ITA1 & ITA2 & ITA3 & ITA4 & ITA5 & ITA6 & ITA7 & ITA8 \\
\hline Brassica pekinensis & SM, fLD ${ }^{\mathrm{a}}$ & SM, fLD & SM & SM & sSM, LD & sSM, S & sSM, LD & SM \\
\hline Brassica rapa var. rapa & SM & $\mathrm{VC}, \mathrm{SM}$ & SM & SM & SM & SM & $\mathrm{VC}, \mathrm{SM}$ & $\mathrm{VC}, \mathrm{SM}$ \\
\hline Capsicum аппиит & $\ldots$ & fVC & $\ldots$ & $\ldots$ & $\ldots$ & $\mathrm{fVC}$ & $\ldots$ & $\ldots$ \\
\hline Chenopodium amaranticolor & SCS & LCS & LCS & LCS & SCS & SCS & LCS & SCS \\
\hline Chenopodium quinoa & sSCS & sSCS & sSCS & fSCS & sSCS & sSCS & sSCS & sSCS \\
\hline Cucumis sativus & $\ldots$ & $\ldots$ & $\ldots$ & $\ldots$ & $\ldots$ & $\ldots$ & $\ldots$ & $\ldots$ \\
\hline Сисurbita реро & fVC & $\ldots$ & $\ldots$ & $\ldots$ & $\ldots$ & fVC & $\ldots$ & $\ldots$ \\
\hline Datura metel & SCS & $\ldots$ & SCS & SCS & SCS & SCS & $\ldots$ & $\ldots$ \\
\hline Datura stramonim & $\ldots$ & $\ldots$ & $\ldots$ & $\ldots$ & $\ldots$ & $\ldots$ & $\ldots$ & $\ldots$ \\
\hline Gomphrena globosa & LNS, NSS & LNS, NSS & LNS, NSS & LNS, NSS & LNS, NSS & $\ldots$ & $\ldots$ & $\ldots$ \\
\hline Lactuca sativa & $\ldots$ & $\ldots$ & $\ldots$ & $\ldots$ & $\ldots$ & $\ldots$ & $\ldots$ & $\ldots$ \\
\hline Lycopersicon esculentum & $\ldots$ & $\ldots$ & $\mathrm{VC}$ & $\mathrm{VC}$ & $\mathrm{VC}$ & $\mathrm{VC}$ & LCD, NSS & LCD, NSS \\
\hline Matthiola incana & SM & SM & SM & SM & $\mathrm{SM}$ & SM & SM & $\mathrm{SM}$ \\
\hline Nicotiana benthamiana & SM, LD & SM, LD & SM, LD & sSM, PD & sSM, LD & SM, LD & SM, LD & sSM, LD \\
\hline Nicotiana glauca & SCS & $\ldots$ & $\ldots$ & SCS & $\ldots$ & SCS & $\ldots$ & SCS \\
\hline Nicotiana glutinosa & LNS, NSS & LNS, NSS & LNS, SM & LNS, NSS & LNS, SM & LNS, SM & LNS, NSS & LNS, NSS \\
\hline Nicotiana rustica & LCS, NSS & LCS, NSS & LCS, SCR & $\ldots$ & SCS & LNS, NSS & LCS, NSS & $\ldots$ \\
\hline Nicotiana tabacum cv. Burley 64 & LNS, NSS & LND, NSS & LNS, NSS & LND, NSS & LNS, NSS & LNS, NSS & LNS, NSS & LNS, NSS \\
\hline Ocimum basilicum & $\ldots$ & $\ldots$ & $\ldots$ & $\ldots$ & $\ldots$ & $\ldots$ & $\ldots$ & $\ldots$ \\
\hline Petunia hybrida & SM & SCD & SM & SM & SM & SM & SCD & SM \\
\hline Phaseolus vulgaris & $\ldots$ & $\ldots$ & $\ldots$ & LND & $\ldots$ & $\ldots$ & LND & LND \\
\hline Physalis floridana & LNS, NSS & $\ldots$ & LNS, NSS & LCD, sSM & LNS, NSS & LNS, NSS & $\ldots$ & $\ldots$ \\
\hline Physalis oxycarpa & SM & SCS & SM & SCS & SM & SM & SM & SM \\
\hline Pisum sativum & $\ldots$ & LND, NSS & LND, NSS & $\ldots$ & LND, NSS & $\ldots$ & $\ldots$ & $\ldots$ \\
\hline Sonchus oleraceus & LNS, NSS & LND, NSS & $\ldots$ & $\ldots$ & $\ldots$ & LND, NSS & $\ldots$ & LND, NSS \\
\hline Tetragonia expansa & LCS, NSS & LCS, NSS & LCS, NSS & LCS, NSS & LCS, NSS & LCS, NSS & $\ldots$ & LCS, NSS \\
\hline Zinnia elegans & SM & SM & $\mathrm{VC}$ & SM & SM & SM & SM & $\mathrm{VC}$ \\
\hline
\end{tabular}

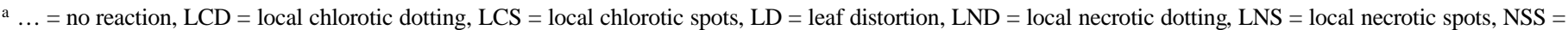
no systemic symptoms, $\mathrm{PD}=$ plant death, $\mathrm{S}=$ stunting, $\mathrm{SCD}=$ systemic chlorotic dotting, $\mathrm{SCR}=$ systemic chlorotic rings, $\mathrm{SCS}=$ systemic chlorotic spots, $\mathrm{SM}=$ systemic mosaic, and $\mathrm{VC}=$ vein clearing. The letters $\mathrm{f}$ and $\mathrm{s}$ in front of the reaction codes refer to the intensity of the reaction: $\mathrm{f}=$ faint and $\mathrm{s}=$ severe.

TABLE 4. Reactions of economically important regional plants to turnip mosaic virus isolates

\begin{tabular}{|c|c|c|c|c|c|c|c|c|}
\hline \multirow[b]{2}{*}{ Species } & \multicolumn{8}{|c|}{ Isolate } \\
\hline & ITA1 & ITA2 & ITA3 & ITA4 & ITA5 & ITA6 & ITA7 & ITA8 \\
\hline Brassica oleracea & $\ldots^{\mathrm{a}}$ & $\ldots$ & $\ldots$ & $\ldots$ & $\ldots$ & $\ldots$ & $\ldots$ & $\ldots$ \\
\hline Brassica oleracea var. botrytis & $\ldots$ & $\ldots$ & $\ldots$ & $\ldots$ & $\ldots$ & $\ldots$ & $\ldots$ & $\ldots$ \\
\hline Brassica ruvo & $\ldots$ & $\ldots$ & fVC & sVC & $\mathrm{VC}, \mathrm{SCS}$ & VC & $\ldots$ & $\mathrm{VC}$ \\
\hline Brassica rapa var. rapa & $\mathrm{VC}$ & $\mathrm{VC}$ & $\mathrm{VC}$ & $\mathrm{VC}, \mathrm{VN}$ & $\mathrm{SM}$ & $\mathrm{VC}$ & $\mathrm{VC}$ & $\mathrm{VC}$ \\
\hline Diplotaxis erucoideses & fLCD & $\ldots$ & $\ldots$ & $\ldots$ & $\ldots$ & $\ldots$ & fLCD & fLCD \\
\hline Eruca sativa & LNS, SM & LCR & VB & LNS, VN, SM, PD & LNS, VC, SM, PD & LNS, VC, SM, PD & SM, VC & SM, VC \\
\hline Raphanus sativus & $\ldots$ & $\ldots$ & $\ldots$ & $\mathrm{SM}, \mathrm{P}$ & $\ldots$ & $\ldots$ & LCD & $\ldots$ \\
\hline
\end{tabular}

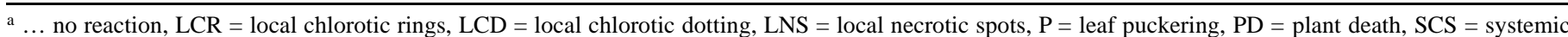
chlorotic spots, $\mathrm{SM}=$ systemic mosaic, $\mathrm{VB}=$ vein banding, $\mathrm{VC}=$ vein clearing, and $\mathrm{VN}=$ veinal necrosis. The letters $\mathrm{f}$ and $\mathrm{s}$ in front of the reaction codes refer to the intensity of the reaction: $\mathrm{f}=$ faint and $\mathrm{s}=$ severe.

Seven economically important species, mostly cultivated and commercialized in the Campania region, were also tested for reaction to the TuMV isolates (Table 4). The two B. oleracea varieties were immune to all isolates. This is consistent with the fact that TuMV has never been reported infecting this species in Campania and only once in Italy (31). On the other hand, Eruca sativa (cultivated rocket) and B. rapa var. rapa were susceptible to all TuMV isolates. Only isolates ITA1, ITA7, and ITA8 could infect Diplotaxis erucoides (wild rocket). Systemic infections were also produced in B. ruvo by the ITA3, ITA4, ITA5, and ITA6 isolates. Raphanus sativus was susceptible only to ITA4 and ITA7. Thus, host range and symptomatology experiments demonstrated the wide variability among the TuMV isolates and the biological difference of them all.

Reactivities of the Italian isolates, with the exception of ITA8, were further tested against 20 MAb by ELISA (Table 5). No serological differences were observed among the TuMV isolates with 14 of the 20 MAb. Only MAb 75 was found to be specific for a single isolate, ITA2. On the other hand, MAb 70 reacted with all isolates except ITA2. The other MAb reacted with at least three isolates. The isolates could be distinguished from each other by using a combination of MAb 59, 68, 71, and 77, but ITA1 and ITA3 isolates possessed identical serological profiles.
The analysis of the SSCP of the CP gene was carried out to confirm the variability of the TuMV strains at the molecular level. The Canadian strain was included as a reference standard. The isolates produced specific SSCP profiles (Fig. 1). The best difference in the migration patterns was observed among the faster migrating fragments; the slower migrating bands represented partially denatured or renatured species $(11,25,26)$. With the exception of ITA1 and ITA3, isolates could be differentiated from one another. The ITA5 and ITA6 profiles were only slightly different, but repeated experiments showed that the difference was consistent. Interestingly, ITA1 and ITA3, which had the same SSCP profile, reacted identically with the MAb. However, one must be cautious when examining SSCP data. SSCP is dependent on RT-PCR amplification, resulting in products representative of the TuMV isolates. The PCR primers may, in some cases, present amplifications from a sequence that does not represent the majority of the virus population (7).

Considerable biological variation in TuMV isolates has been observed (9) and was recently shown to originate, in part, in the coat protein $(12,19)$. Variability from diverse geographic origin was also reported for potyviruses $(5,23,24,30)$. This study demonstrates that potyvirus variation can also be observed even in a small geo- 


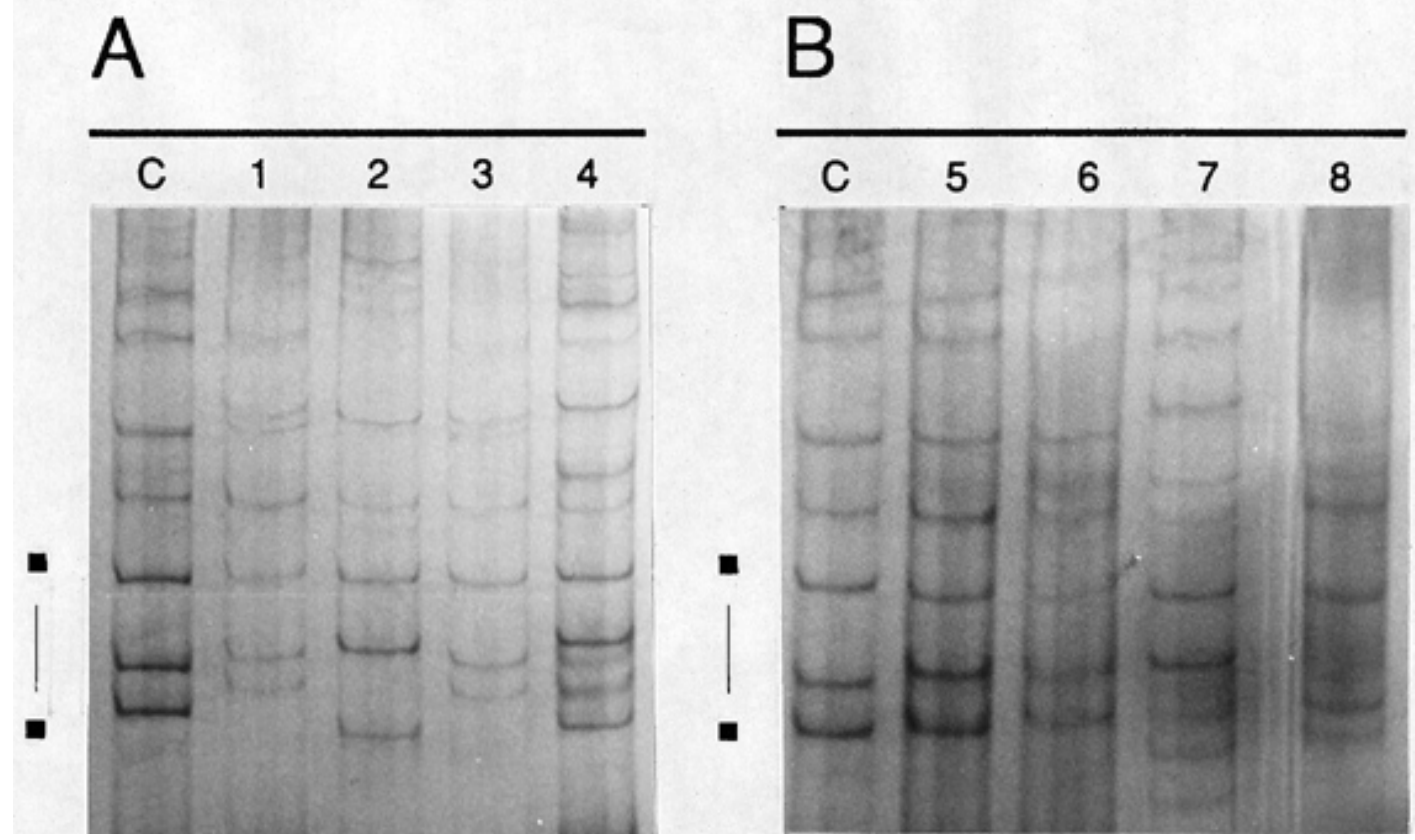

Fig. 1. Single-strand conformation polymorphism (SSCP) patterns given by the reverse-transcriptase polymerase chain reaction products of the turnip mosaic virus isolates. A, The reference standard (Canadian isolate [C]) and the Italian isolates ITA1 (1), ITA2 (2), ITA3 (3), and ITA4 (4). B, The reference standard (Canadian isolate [C]) and the Italian isolates ITA5 (5), ITA6 (6), ITA7 (7), and ITA8 (8). Each isolate produced a specific SSCP profile. The line between the two black squares indicates the region of highest polymorphism among the isolates.

TABLE 5. Reactivity of monoclonal antibodies (MAb) to turnip mosaic virus isolates in enzyme-linked immunosorbent assay

\begin{tabular}{lcccccc}
\hline & \multicolumn{7}{c}{ MAb $^{\mathrm{a}}$} \\
\cline { 2 - 7 } Isolate & 59 & 68 & 70 & 71 & 75 & 77 \\
\hline ITA1 & $+^{\mathrm{b}}$ & - & + & - & - & - \\
ITA2 & - & - & - & + & + & + \\
ITA3 & + & - & + & - & - & - \\
ITA4 & - & + & + & - & - & + \\
ITA5 & - & - & + & - & - & + \\
ITA6 & + & + & + & + & - & - \\
ITA7 & + & + & + & + & - & + \\
\hline
\end{tabular}

${ }^{a}$ MAb 51, 60, 61, 72, 73, 74, 78, and 82 did not react with any of the isolates. MAb 58, 67, 79, 80, and 81 reacted with all the isolates.

${ }^{\text {b }}$ Sample was scored as positive (+) when its colorimetric reading at $450 \mathrm{~nm}$ was at least two times the value of the negative control (healthy Chenopodium quinoa) included in the same plate. $-=$ scored as negative.

graphic region as evidenced by host range, symptoms, serology, and SSCP. Our investigation illustrates the importance of having several classification criteria based on different properties of the virus. For instance, isolates ITA4, ITA5, and ITA6 were assigned to the same pathotype group on B. napus test lines, but differed in host range, symptoms, serology, and SSCP. Similarly, ITA 1 and ITA3, belonging to the same pathotype group, were indistinguishable by serology and SSCP, but had different host ranges and symptoms. The coexistence of several TuMV isolates in a restricted geographic area has important implications for TuMV evolution and epidemiology of the disease. The possibility of coinfections is high, which may lead to a more severe disease. In addition, deployment of resistant cultivars becomes much more problematic.

\section{ACKNOWLEDGMENTS}

We thank M. F. Clark for providing monoclonal antibodies, J. A. Walsh for differential Brassica napus lines, and A. Peluso for the excellent technical assistance. This work was supported, in part, by the Natural Sciences and Engineering Research Council of Canada (J.-F. Laliberté) and by Le Ministère de l'Éducation du Gouvernement du Québec (Coopération Québec-Italie).

\section{LITERATURE CITED}

1. Alioto, D., Stavolone, L., and Aloj, B. 1994. Gravi alterazioni indotte da cauliflower mosaic virus (CaMV) e turnip mosaic virus (TuMV) su Matthiola incana. Inform. Fitopatol. 6:43-46.

2. Bassam, B. J., Gaetano-Anollés, G., and Gresshoff, P. M. 1991. Fast and sensitive silver staining of DNA in polyacrylamide gels. Anal. Biochem. 196:80-83.

3. Camele, I., Nuzzaci, M., Rana, G. L., and Kyriakopoulou, P. E. 1991. Papaver rhoeas L. ospite di due virus patogeni per le piante coltivate. Petria 1:111-115.

4. Clark, M. F., and Adams, A. N. 1977. Characteristic of the microplate method of enzyme-linked immunosorbent assay for the detection of plant viruses. J. Gen. Virol. 34:475-483.

5. Ellis, P., Stace-Smith, R., and de Villiers, G. 1997. Identification and geographic distribution of serotypes of potato virus Y. Plant Dis. 81:481-484.

6. Green, S. K., and Deng, T. C. 1985. Turnip mosaic virus strains in cruciferous hosts in Taiwan. Plant Dis. 69:28-31.

7. Hilf, M. E., Karasev, A. V., Garnsey, S. M., and Dawson, W. O. 1995. Structure of citrus tristeza virus populations: Genetic variation underrepresented by PCR as revealed by northern blot hybridization. Am. Soc. Virol. P1-25:118.

8. Horsewood, P., McDermott, M. R., Stobbs, L. W., Brais, P., and Underdown, B. J. 1991. Characterization of a monoclonal antibody to turnip mosaic virus and its use in immunodiagnosis of infection. Phytoprotection 72:61-68

9. Jenner, C. E., and Walsh, J. A. 1996. Pathotypic variation in turnip mosaic virus with special reference to European isolates. Plant Pathol. 45: 848-856.

10. Kantrong, S., and Sako, N. 1993. Characterization of epitopes recognized by monoclonal antibodies to aphid transmissible and non-transmissible strains of turnip mosaic virus. Arch. Virol. 133:11-20.

11. Koenig, R., Luddecke, P., and Haeberlé, A. M. 1995. Detection of beet necrotic yellow vein virus strain, variants and mixed infections by examining single-strand conformation polymorphisms of immunocapture RT-PCR products. J. Gen. Virol. 76:2051-2055.

12. Lehmann, P., Petrzik, K., Jenner, C., Greenland, A., Spak, J., Kozubek, E., and Walsh, J. A. 1997. Nucleotide and amino acid variation in the coat protein coding region of turnip mosaic virus isolates and possible involvement in the interaction with the brassica resistance gene TuRBO1. Physiol. Mol. Plant Pathol. 51:195-208.

13. Ling, K.-S., Provvidenti, R., and Gonsalves, D. 1995. Detection of turnip mosaic virus isolates using an antiserum to coat protein breakdown products. Plant Dis. 79:809-812.

14. McDonald, J. G., and Hiebert, E. 1975. Characterization of the capsid and cylindrical inclusion proteins of three strains of turnip mosaic virus. 
Virology 63:295-303.

15. Milne, R. G., and Luisoni, E. 1977. Rapid immune electron microscopy of virus preparations. Pages 265-268 in: Methods in Virology. K. Maramorosh and H. Koprowski, eds. Academic Press, New York.

16. Murphy, F. A., Fauquet, C. M., Bishop, D. H. L., Ghabrial, S. A., Jarvis, A. W., Martelli, G. P., Mayo, M. A., and Summers, M. D. 1995. Virus taxonomy: Sixth report of the international committee on taxonomy of viruses. Arch. Virol. Suppl. 10:348-357.

17. Nicolas, O., and Laliberté, J.-F. 1991. The use of PCR for cloning of large cDNA fragments of turnip mosaic virus. J. Virol. Methods 32:57-66.

18. Nicolas, O., and Laliberté, J.-F. 1992. The complete nucleotide sequence of turnip mosaic potyvirus RNA. J. Gen. Virol. 73:2785-2793.

19. Petrzik, K., and Lehmann, P. 1996. Classification of turnip mosaic virus isolates according to the $3^{\prime}$-untranslated region. Acta Virol. 40:151-155.

20. Pound, G. S., and Walker, J. C. 1945. Differentiation of certain crucifer viruses by the use of temperature and host immunity reactions. J. Agric. Res. 71:255-278.

21. Provvidenti, R. 1980. Evaluation of Chinese cabbage cultivars from Japan and the People's Republic of China for resistance to turnip mosaic virus. J. Am. Soc. Hortic. Sci. 105:571-573.

22. Provvidenti, R., and Hampton, R. O. 1992. Sources of resistance to viruses in the Potyviridae. Arch. Virol. Suppl. 5:189-211.

23. Rajamäki, M., Merits, A., Rabenstein, F., Andrejeva, J., Paulin, L., Kekarainen, T., Kreuze, J. F., Forster, R. L. S., and Valkonen, J. P. T. 1998. Biological, serological, and molecular differences among isolates of potato A potyvirus. Phytopathology 88:311-321.

24. Saiz, M., Dopazo, J., Castro, S., and Romero, J. 1994. Evolutionary relationships among bean common mosaic virus strains and closely re- lated potyviruses. Virus Res. 31:39-48.

25. Sheffield, V. C., Beck, J. S., Kwitek, A. E., Sandstrom, D. W., and Stonet, E. M. 1993. The sensitivity of single-strand conformation polymorphism analysis for the detection of single base substitutions. Genomics 16:325-332.

26. Shi, N., Chen, J., Wilson, T. M. A., Macfarlane, S. A., Antoniw, J. F., and Adams, M. J. 1996. Single-strand conformation polymorphism analysis of RT-PCR products of UK isolates of barley yellow mosaic virus. Virus Res. 44:1-9.

27. Stobbs, L. W., and Shattuck, V. I. 1989. Turnip mosaic virus strains in southern Ontario, Canada. Plant Dis. 73:208-212.

28. Tomlison, J. A. 1970. Turnip mosaic virus. CMI (Commonw. Mycol. Inst.)\AAB (Assoc. Appl. Biol.) Descr. Plant Viruses 8.

29. Tomlison, J. A. 1987. Epidemiology and control of virus diseases of vegetables. Ann. Appl. Biol. 110:661-681.

30. Tordo, V. M. J., Chachulska, A. M., Fakhfakh, H., Le Romancer, M., Robaglia, C., and Astier-Manifacier, S. 1995. Sequence polymorphism in the $5^{\prime} \mathrm{NTR}$ and in the P1 coding region of potato virus Y genomic RNA. J. Gen. Virol. 76:939-949.

31. Vicchi, V., and Bellardi, M. G. 1989. Black ringspots in cauliflower in Italy. Adv. Hortic. Sci. 3:33-35.

32. Walsh, J. A. 1989. Genetic control of immunity to turnip mosaic virus in winter oilseed rape (Brassica napus ssp. oleifera) and the effect of foreign isolates of the virus. Ann. Appl. Biol. 115:89-99.

33. Yang, F., Cai, S. H., Xu, L., and Feng, L. X. 1992. The establishment of hybridoma cell line secreting specific monoclonal antibodies against turnip mosaic virus and analysis of properties of the McAbs. Chin. J. Biotechnol. 8:342-347. 